\section{Redefiniendo la profesión}

En este número de EDUCACIÓN MÉDICA publicamos la colaboración especial del Profesor J. A. Rodríguez en el que comenta con espíritu crítico la encuesta que su equipo llevó a cabo en el universo del Colegio de Médicos de Barcelona y que creemos representativo de la situación en una sociedad avanzada. El análisis sobre los factores de cambio que desde el entorno social y del ámbito de trabajo están incidiendo sobre la profesión parece digno de ser tenido en cuenta. Asimismo nos parece encomiable que, en unos momentos en que la profesión parece abatida y gravemente afectada por el síndrome del "quemado" o burn-out, el equipo del Prof. Rodríguez haya sabido hacer emerger la actitudes positivas existentes en la profesión y su creencia en los valores del Profesionalismo.

¿Por qué una revista especializada en educación se ocupa de estas cuestiones? ¿Acaso vale la pena ofrecer a los educadores este tipo de cuestiones? Se nos aparece como evidente el que los retos presentes a las profesiones lo son asimismo para los sistemas educativos y por ello, deben ser tenidos en cuenta por los educadores. Quisiéramos hacer memoria del principio del Juramento Hipocrático por el que la función educativa no puede ser considerada exclusivamente como una función especializada sino que es substancialmente inseparable de la medicina y por tanto afecta a todos los profesionales.

Es hora de recordarnos que la educación médica no es una finalidad en si misma sino que está al servicio de la sociedad y por tanto debe producir profesionales capaces, esto es que estén dotados de las competencias (conocimientos, habilidades y actitudes) necesarias para rendir los servicios que la sociedad espera de ellos. En tanto que el sistema educativo deba estar orientado al producto (outcome) es lógico tener en cuenta aquellos factores del entorno que inciden sobre la competencia profesional exigible y en consecuencia deberán adaptarse los procesos educativos para poder alcanzar los objetivos deseables.

Albert Oriol-Bosch

\section{Re-defining the profession}

The present issue of EDUCACIÓN MÉDICA offers a special collaboration of Professor Rodríguez reflecting critically on the survey carried out by his research team on medical profession sampled from the Barcelona's Medical Association membership. The analysis of the impinging factors (social environment and organizational working environment) on the medical competencies demanded from the physicians showed trends well identified. It is also worth of attention the ability of the surveyors in extracting from the surveyed something more than the fashionable disappointment of the profession "burn-out syndrome" to make apparent that the physicians, in spite of it all, have not forgotten but still believe on the values of medicine, something that can be encapsulated into the concept of Professionalism.

Why should a specialized journal on education be concerned on this topic? Why such a paper should be of interest to educationalist? We consider as self-evident that the challenges posed at the beginning of the XXI ${ }^{\text {st }}$ century and impinging into the competences of the medical profession also challenge the educational system understood in its broadest sense (Hippocratic Oath) involving, therefore not only the professional educationalist but the educational function of every physician.

It is already time to remember before educationalist are reminded that medical education is not an end by itself but serve the social function of producing capable professionals endowed with the proper competencies (knowledge, abilities and attitudes) to serve society as it is expected from the medical profession.

Albert Oriol-Bosch 